Brit. J. Ophthal. (1959) 43, 40.

\title{
IN VITRO SWELLING OF THE KITTEN RETINA INDUCED BY SODIUM FLUORIDE INHIBITION*
}

BY

\author{
CLIVE GRAYMORE
}

Department of Pathology, Institute of Ophthalmology, University of London

IN a previous report (Graymore, 1958) methods have been described for the rapid removal of rat retinae and the subsequent accurate determination of their Wet-weight:Dry-weight ratios following a period of incubation with Krebs-Ringer-Bicarbonate supplemented with glucose. It was shown that addition of sodium fluoride to the medium resulted in a tissue oedema. This was explained on the basis that living cells are not necessarily in osmotic equilibrium with their environment, and that the osmotic pressure of the cells is maintained at a higher level as a steady state, by some process requiring metabolic energy to pump water outwards through the cell membrane. This concept, and the supporting evidence, has been reviewed elsewhere (Robinson and McCance, 1952; Robinson, 1954). Ashton, Graymore, and Pedler (1957) induced vaso-obliteration in the kitten retina by intravitreal injection of sodium fluoride, and suggested that external pressure due to retinal oedema may play some role in this vessel closure. The present communication is designed to show that the retina of the kitten responds to in vitro treatment with sodium fluoride in the same way as that of the rat.

\section{Methods}

Both eyes were removed from an anaesthetized (Nembutal) 6-weeks-old kitten, and the retinae were excised as rapidly as possible. Each retina was cut into fragments and incubated for 2 hours in a separate flask containing standard KrebsRinger-Bicarbonate buffer fortified with $400 \mathrm{mg}$. per cent. glucose, and gassed with 5 per cent. $\mathrm{CO}_{2}-95$ per cent. $\mathrm{O}_{2}$. In addition to the above medium, sodium fluoride was added to one of the incubating flasks to give a final concentration of $0.05 \mathrm{M}$. and an equivalent concentration of sodium chloride was added to the other (control) flask. The efficiency of the sodium fluoride inhibition was checked manometrically.

After the period of incubation, the retinal fragments were removed and their Wet-weight:Dry-weight ratios determined as previously (Graymore, 1958).

\footnotetext{
* Received for publication March 24, 1958.
} 


\section{Results}

The Table shows that there is a statistically significant increase in the ratio of the fluoride treated retinae.

TABLE

STATISTICALLY SIGNIFICANT INCREASE IN $\frac{\text { WET-WEIGHT }}{\text { DRY-WEIGHT }}$ RATIO OF RETINAL FRAGMENTS INCUBATED WITH SODIUM FLUORIDE

\begin{tabular}{|c|c|c|c|c|}
\hline \multicolumn{3}{|c|}{ Series } & Number of Determinations & Wet-weight:Dry-weight Ratio \\
\hline Control & $\cdots$ & $\cdots$ & 5 & $5 \cdot 7 \pm 0 \cdot 21$ \\
\hline Fluoride-treated & & $\cdots$ & 6 & $\begin{array}{l}7 \cdot 7 \pm 0.25 \\
p=<0.001\end{array}$ \\
\hline
\end{tabular}

\section{Conclusions}

These results indicate that, under the conditions employed, the kitten retina takes in water when fluoride is present in the medium. It should be stressed that glucose was the only substrate provided, and that the addition of $0.05 \mathrm{M}$. sodium fluoride, by virtue of its inhibitory action on glycolysis (Dickens and Greville, 1932), would prevent the adequate utilization of this substrate as a source of energy. The inference to be drawn from these experiments, therefore, is not that fluoride will induce retinal oedema in vivo, but that, if the only available source of energy is removed, then retinal tissue will swell.

There is not yet sufficient evidence to implicate imbibition of water by the retina in the process of fluoride vaso-obliteration, but these results indicate that suitable metabolic inhibition may promote water uptake by the retina. The fact that the fluoride effect can be observed only in immature retinae (Ashton and others, 1957) may reflect a changing metabolic pattern with age.

I would like to thank Prof. Norman Ashton for his advice and encouragement in this work. My thanks are also due to Mr. A. Lakeman for his valuable technical assistance, and to Miss E. FitzGerald for secretarial help. I wish to acknowledge the assistance of the Medical Research Council by providing a grant towards the expenses of this work.

\section{REFERENCES}

Ashton, N., Graymore, C., and Pedler, C. (1957). Brit. J. Ophthal., 41, 449.

Dickens, F., and Greville, G. D. (1932). Biochem. J., 26, 1546.

GRAYMORE, C. (1958). Brit. J. Ophthal., 42, 348.

Robinson, J. R. (1954). Symposia of the Society for Experimental Biology, 8, 42. Cambridge University Press, London.

and McCance, R. A. (1952). Ann. Rev. Physiol., 14, 115. 